\title{
The Reproductive Patterns of Two South Australian Mytilid Species: Brachidontes erosus (Lamarck, 1819) and Brachidontes rostratus (Dunker, 1857).
}

\author{
Pola Reproduksi Dua Jenis Mytilid di Perairan Australia Selatan: Brachidontes erosus \\ (Lamarck, 1819) dan Brachidontes rostratus (Dunker, 1857)
}

\author{
Medy Ompi \\ Fakultas Perikanan dan Ilmu kelautan, Universitas Sam Ratulangi \\ Kampus-Bahu, Manado, Sulawesi Utara, 95515 E-mail: medyompi@yahoo.com
}

\begin{abstract}
Abstrak
Pola reproduksi dari dua jenis Kerang, Brachidontes erosus dan Brachidontes rostratus di perairan laut Port Lincoln, Australia Selatan, Australia ditentukan berdasarkan ukuran telur, pola settlement selama 18 bulan, dan juga aktivitas pemijahan di laboratorium. Gamet dari B. erosus nampak mulai berkembang pada bulan Februari dan mencapai puncak pada bulan September, sekaligus sebagai awal pemijahan, yang mencapai klimaks pada bulan November sampai bulan Januari. Jenis B. rostratus nampak memiliki dua puncak matang gonad, yang satu terjadi di bulan Juli dan puncak matang gonad kedua terjadi pada bulan November sampai Februari. Puncak pemijahan dari jenis ini berada di bulan Februari sampai dengan April. Kerang $B$. erosus memiliki ukuran diameter telur lebih besar dibandingkan dengan jenis kerang B. rostratus. Faktor-faktor seperti makanan, suhu perairan, karakter kerang dan kondisi perairan lainnya kemungkinan mempengaruhi pola reproduksi kedua jenis kerang ini.
\end{abstract}

Key Word: Reproduction patterns, mussels, Brachidontes, Mytilids species, South Australia

Diterima: 08 Desember 2005, disetujui: 13 Maret 2006

\section{Introduction}

Two species, Brachidontes rostratus and Brachidontes erosus are common in Southern Australia waters. They are found on various substrata like rock, mixed hard substratum and coarse sand, in both intertidal and sub-tidal areas (Lamprell and Healy, 1998).

The reproductive patterns of these two species can vary as result of many factors, such as times and different environmental conditions. In many marine mussels gonad development starts in winter and reaches a peak in late winter with spawning occurring in spring or summer, followed by a period of resting. This reproductive pattern has been reported for many mytilid species including
Mytilus edulis, M. trossulus (Toro et al., 2002), and Perna canaliculus (Buchanan, 2001). A mussel may develop their gonads during periods of high salinity while spawning occurs when salinity is low (Giese and Pearse, 1979). Tides may indirectly influence the reproductive activity of mussels, particularly during low tide when the organisms may be exposed to the sun, and are unable to feed.

Food availability may also influence reproductive activity. Many studies have shown that gonad development depends on food availability, particularly the spring plankton bloom, which allows increased gonad development (Thorarinsdottir, 1996; Myrand et al., 2000).

Reproduction activities vary between mytilid species. For example, Wilson and 
Hodgin (1967) reported that Xenotrobus pulex and $M$. planulatus in Western Australian waters ripen in April until July, and first spawning takes place in late July followed by a second spawning in September. For $B$. variabilis, gametes matured during January and February with spawning occurring between March and April in the same waters (Wilson and Hodgin, 1967).

Surprisingly, there is a lack of reproductive information for these two species, $B$. rostratus and B. erosus. Morton (1988) predicted that $B$. erosus spawn in summer and autumn in South Australian waters interpolating from studies of $B$. variabilis and Septifer bilocularis in Western Australian waters (Wilson and Hodgkin, 1967).

In this paper I describe the reproduction patterns of two South Australian mytilid species, B. erosus and B. rostratus, focusing on maturity, spawning time, and eggs size.

\section{Materials and methods}

Two locations on the Eyre Peninsula, South Australia were chosen as sampling locations. These were Coffin Bay, where patches of $B$. rostratus occur, and Trinity Heaven where B. erosus is found.

Mussels were removed from their habitat by carefully cutting their byssus. They were immediately brought to the laboratory at the Lincoln Marine Science Centre, Port Lincoln, South Australia. At least eight individuals of large mussel size from each species were cleaned and sorted, then used for measurement of oocyte diameter. Each mussel was opened carefully by cutting the adductor muscle. Three different thin sections of each gonad were cut and squashed on a microscope glass slide with drops of filtered seawaters added, and then were examined under a microscope to measure the diameter of the oocytes, by measuring the longest and widest perpendicular axes (Grand and Tyler, 1983). Eleven oocytes from each thin section were measured.

Mussels were induced to spawn by thermal stimulation. About 15 to 40 individuals were washed and induced by a rapid increase in the water temperature from Biota Vol. XI (2), Juni 2006 $14^{\circ} \mathrm{C}$ to $22^{\circ} \mathrm{C}$. Saltwater ice cubes were used to reduce the seawater temperature to $14^{\circ} \mathrm{C}$ in the summer. When the mussel responded, gametes were released. Then, the mussels were individually placed in $500 \mathrm{ml}$ plastic containers, or 11 Pyrex beakers, with 200 $250 \mathrm{ml}$ seawater that had been passed through a $1 \mu \mathrm{m}$ filter.

Mussels were also stimulated to spawn by a slow increase of the seawater temperature. Spawning was induced by leaving the individual mussels in $500 \mathrm{ml}$ plastic containers with $200 \mathrm{ml}$ of filtered seawater, allowing the temperature to rise to room temperature. The collected eggs were rinsed in filtered seawater and diluted to 500 $\mathrm{ml}$, before $0.5 \mathrm{ml}$ of eggs suspension was transferred to a hemocytometer and measured under a microscope.

Settlement was monitored in the field to determine the presence of larvae in the water as a result of spawning activities. The larvae were allowed to settle on nylon scouring pads that mimic a tread-like substratum. The scouring pad was fitted on top of a concrete brick. Four replicated bricks were placed at each sampling site among adult populations. Each brick was placed within a patch about 5 to $10 \mathrm{~m}$ apart. The bricks were replaced monthly.

In the laboratory, living settlers were extracted by using a combination of washing through a sieve and an anesthetic technique (Holme and McIntyre, 1971). All settlers were then examined under a dissecting microscope for sorting and counting.

\section{Results}

\section{Gonad maturation}

The gonad cycles of the South Australian mytilids $B$. erosus, and $B$. rostratus interpolated from ooycte diameter is shown in Fig. 1. The oocyte diameter varied with time for each of the species, reflecting the difference in reproductive cycles.

The mean oocyte diameter of $B$. erosus increased from January to February, reaching $70.07 \mu \mathrm{m} \pm 1.07$ (95\% Confidence Interval (CI)) in April, and a peak of maturation in 
September with a mean of $73.75 \mu \mathrm{m} \pm 1.79$ (95\% CI). Spawning commenced in September and October where a reduction of oocyte diameter was evident. The major spawning was between November and January where the mean oocyte diameter was reduced from a mean of $66 \mu \mathrm{m}$ to $48 \mu \mathrm{m}$. The mean oocyte diameter increased again in February and up to
May, which indicated that gamete development had started again.

A peak maturation of gametes for $B$. rostratus was observed in January with a mean of $65.02 \mu \mathrm{m} \pm 2.07$ (95\% CI). This mytilid spawned from February until April, when the mean oocyte diameter decreased sharply. A second spawning period might occur in August, because a decrease of the oocyte size between July and August was observed.

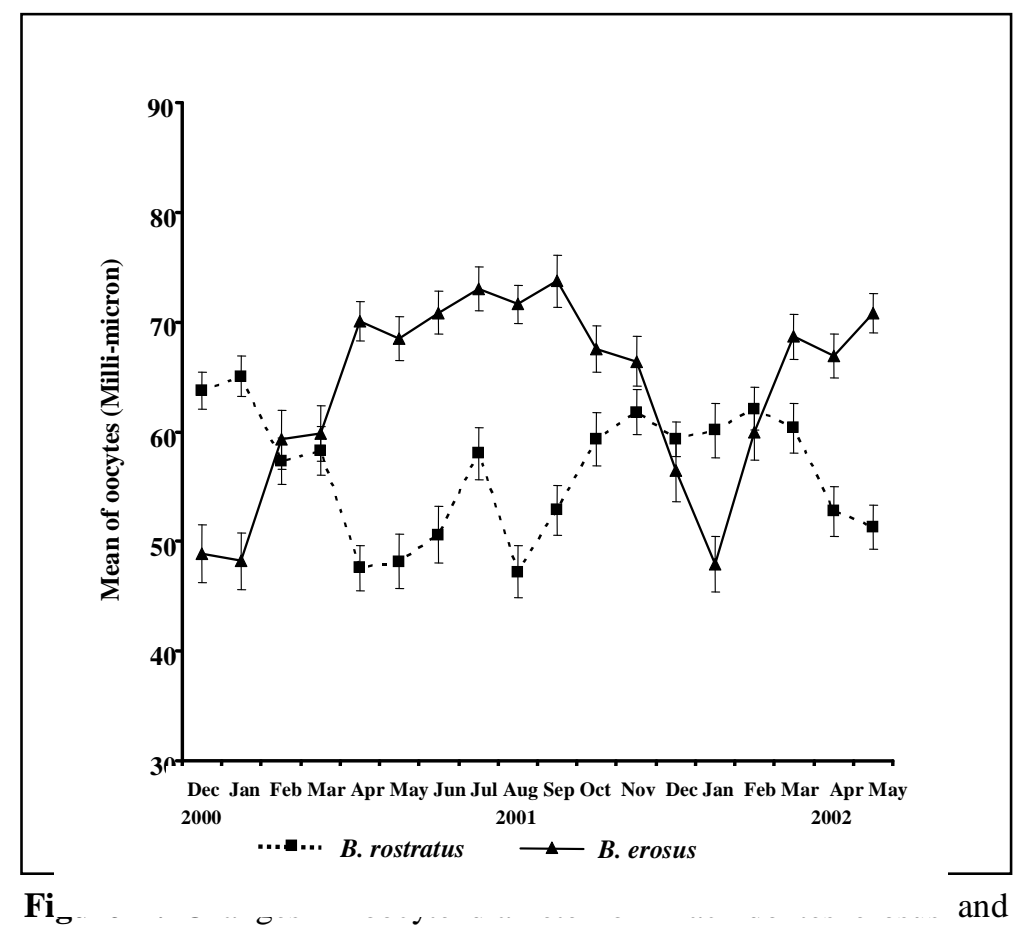

Brachidontes rostratus from December 2000 to May 2002.

Error bars are $95 \%$ confidence interval (CI).

Gamete development started again from September up to November with an increasing mean oocyte diameter of $52.84 \mu \mathrm{m} \pm 2.45$ (95\% CI) in September to $61.79 \mu \mathrm{m} \pm 2.11$ (95\% CI) in November. The mean oocyte diameter fluctuated from November to February and then decreased sharply indicating spawning from March to May (Fig. 1).

\section{Larval settlement}

Settlement of B. rostratus was observed throughout the year with one peak in March, 2001, and in April 2002 (Fig. 2). Mean settlement was 12.5 individuals in January and about 7 in February, 2001. This value increased significantly in March with a mean of 285, and then decreased sharply to 12.5 in April. The settlement stayed relatively low from May 2001 until March 2002. It increased significantly again in April, indicating a settlement peak during 2002.

A peak in settlement for B. erosus in January 2001 reduced by March and April after which there were $<10$ settlers (Fig. 1). The lowest number of settlers was found in June, July, and September with a mean of 1 settler. Settlement increased again in December 2001 with a mean of 64 settlers, and then gradually reduced in January and February to remain at the same level from March until May 2002. The maximum settling activity also followed the spawning activity of this species (Fig. 1 and 2). 

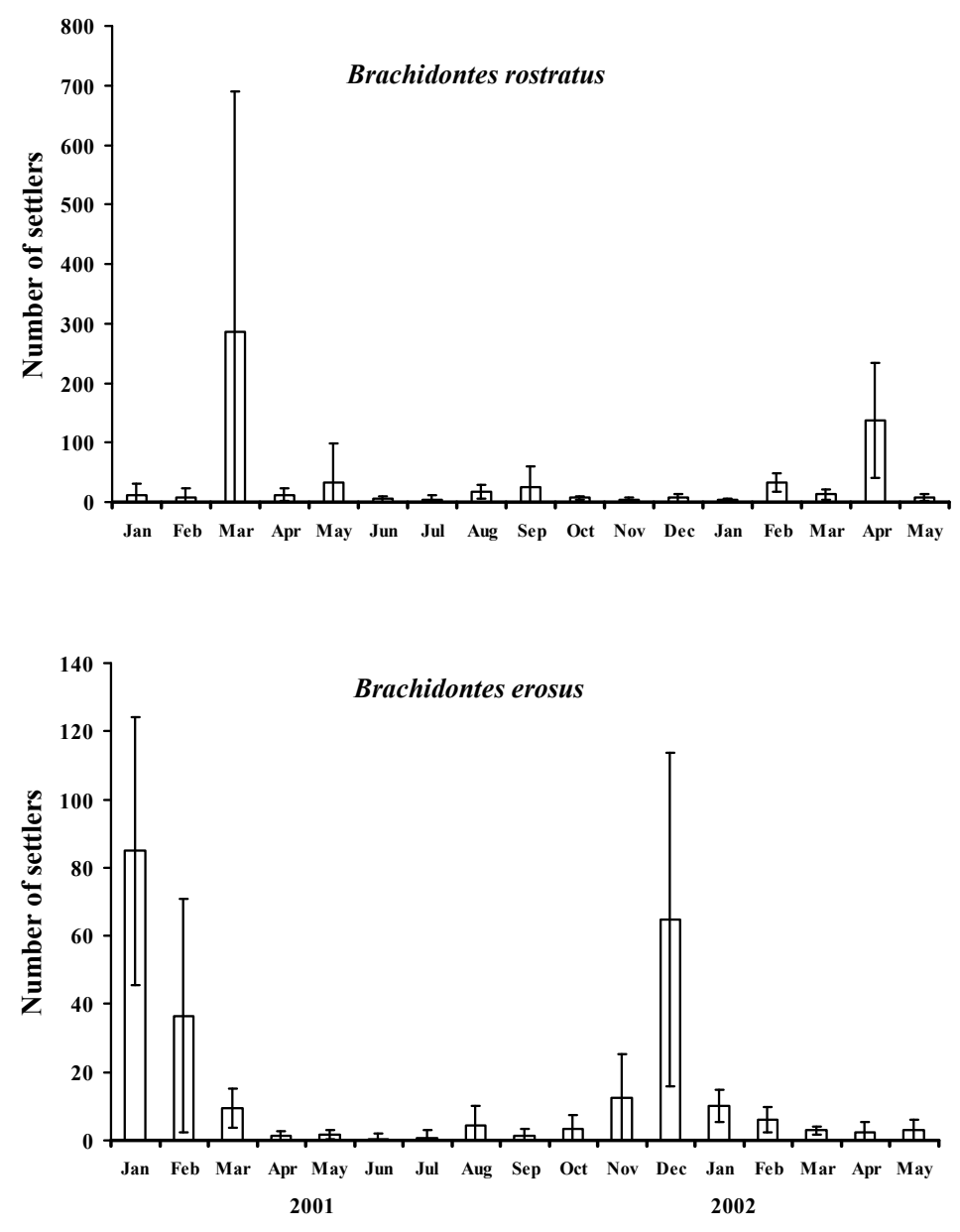

Figure 2. Mean settlement of Brachidontes rostratus and Brachidontes erosus collected from scourers from January 2001 until April 2002. Error bars are $95 \%$ CI.

\section{Induction of Spawning in the Laboratory}

B. rostratus, most mussels spawning occurred as a response to a slowly increasing temperature from 20 to $23^{\circ} \mathrm{C}$ (Table I). This was also the case for $B$. erosus. It spawned when seawater temperatures increased slowly from 19 to $23^{\circ} \mathrm{C}$. Furthermore, spawning of these two species occurred at midnight or early in the morning.

The eggs of each species varied in size. The eggs of $B$. rostratus were 76 to $81 \mu \mathrm{m}$ in diameter, while B. erosus eggs were 91 to 106 $\mu \mathrm{m}$ in diameter. B.erosus eggs appear to have a larger diameter than $B$. rostratus.

Tabel 1. Temperature ranges where spawning of four mytilids species occurred in the laboratory

\begin{tabular}{clc}
\hline \hline \multicolumn{1}{c}{ Species } & Temperature ${ }^{\mathbf{0}} \mathbf{C}$ \\
\hline \hline 1. & Brachidontes rostratus & $19-23$ \\
2. & Brachidontes erosus & $20-23$ \\
\hline \hline
\end{tabular}




\section{Discussion}

\section{Maturity}

The reproductive cycles of the South Australian mytilids populations found at Port Lincoln and the surrounding waters showed different maturation and spawning time for each species. One peak of reproductive activity was observed in $B$. erosus, where gametes development increased from February to April and reached a peak in September. This mussel start to release its eggs and sperms in October and have a major spawning event in November and January. A spawning activity was observed in the laboratory, and in the field, from November to January, and a peak of settling activity was observed in January during the first year of observation, and in December during the second year of observation. Settling activities indicated that many larvae were in the water during the spawning time and were ready to settle when they reached the pediveliger stage.

Two peaks of maturation were observed for $B$. rostratus. The first maturation was in January, followed by a major spawning from February to April. The second maturation occurred in July. Partial spawning might take place in August, because the mean oocyte size was reduced in July until August. However, no spawning activity was observed in the laboratory either when a small peak in oocyte diameter was reached in June, nor when it decreased in July until August.

Food availability and species characteristics may influence to reproduction patterns of these two species. Food sources such as phytoplankton tend to be abundant when sea water temperatures increase in spring until summer in temperate and sub-tropic waters (Myrand et al., 2000). Food sources might also be abundant during these times in Port Lincoln, where these mussels might get a peak of taking their food from the water and transfering it to gonad development during these times. Many marine mytilid species such as M. edulis in Denmark's (Europe) waters (Svane and Ompi, 1993), M. planulatus (galloprovincialis) in Sydney's waters, Australia (Wisely, 1964), and Perna canaliculus in New Zealand's water (Buchanan, 2001), mature and spawn in spring or from spring until summer. According to Rodhouse et al., (1984), food abundance can lead to more than one peak of reproduction in marine mussels. This is probably the case for $B$. rostratus, but may not be for $B$. erosus in this study.

$B$. erosus may be called a summer species as it takes an abundance of food from waters in spring until summer, and as major spawning only comes when sea water temperature reach summer maximums. This reproductive pattern resembles the reproductive pattern of $B$. variabilis and Septifer bilocularis in western Australian waters (Wilson and Hodgkin, 1967) and $B$. variabilis in Hong Kong waters (Morton, 1988).

$B$. erosus and $B$. rostratus appeared to have gonad development during winter times. This patter is similar to mussels, Mytilus trossulus, in Port Valdez, Alaska, M. edulis from the North Sea (Toro et al., 2002), and $M$. planulatus in Sydney's waters, Australia (Wisely, 1964). However, a different pattern appeared for certain species of marine bivalves in warm waters such as the oyster, Pinctada margaritivera, in which reproductive activity occurs during the warm seasons (Povreau et al., 2000).

\section{Spawning}

As a result of spawning activities, larvae occurred in the water column. A peak in settlement activity followed oocyte development and spawning. However, settlement occurred throughout the year for all species. Trickle spawning may explain this pattern because a proportion of the mussels were mature throughout the year. It might also be caused by variation in the environments conditions. This phenomenon was similar to the spawning pattern observed in Brachidontes exustus (Sweeney and Walker, 1989).

Mussels may respond to a variety of stimuli by releasing their sperm and eggs into the waters column after their gametes reach the maturation stage. The stimuli be temperature in this study. B. rostratus and B. erosus responded well to slow changing seawater

Biota Vol. XI (2), Juni 2006 
temperatures. Both mussels spawned when seawaters temperature was above $19^{\circ} \mathrm{C}$. Wisely (1964) reported that mussels of Mytilus planulatus (galloprovincialis) spawned when seawaters reached $14^{\circ} \mathrm{C}$. This implies that mussels of $B$. erosus and $B$. rotratus require higher temperature to spawn than $M$. planulatus (galloprovincialis).

South Australian seawater temperatures, including Port Lincoln and surrounding waters, range between 12 to $14^{\circ} \mathrm{C}$ in winter, and between 19 to $24^{\circ} \mathrm{C}$ in summer, and can reach $26^{\circ} \mathrm{C}$ in some part of the Spencer Gulf (Shepherd and Thomas, 1989). The summer condition is the likely favourable seawater temperature condition for $B$. erosus and $B$. rotratus.

Spawning in warm water conditions for marine mussels, especially with planktonic larvae, can be an advantage. Food sources are abundant at this time, in which planktonic larvae can have a continual food supply. This may ensure adequate nutrition for developing planktonic larvae, such as suggested by Pouvreau et al. (2000).

\section{Egg sizes}

Differences in egg size among the study species can be related to larval dispersal time and developmental patterns (Zardus and Martel, 2002). B. rostratus has planktontrophic larval development, while $B$. erosus probably has a feeding lecithotrophic larva where feeding may be facultative.

In general, larvae that feed on plankton (planktotrophic) stay longer in the water column than larvae that feed on their yolk (lecithotrophic). A planktotrophic larva has a wider dispersal, but also has a larger chance to be preyed upon, as well as a large risk of currents drifting it into un-favourable areas that may cause high mortality rates. Lecithotrophic larvae can remain in the water column for less time and hence are less prone to predation and accidental drift to unfavourable areas.

\section{Acknowledgements}

I would like to express my gratitude to Dr. Ib. Svane for help and encouragement. Biota Vol. XI (2), Juni 2006
Thanks are also to Dr Jeremy Robinson for support and valuable discussion. Thanks are especially due to Jeremy Barnet for stimulating discussion and assistance with the field work. The School of Biological Sciences, Flinders University, Australia, supported this study.

\section{References}

Buchanan, S. 2001. Measuring reproductive condition in the Greenshell mussel Perna canaliculus. New Zealand Journal of Marine and Freshwater Research. 35: 859-870.

Giese, A.C. and Pearse, J.S. 1979. Reproduction of marine invertebrates. Volume V. Academic Press, New York, USA.

Grant, A. and Tyler, P.A.1983. The analysis of data in studies of invertebrate reproduction. II. The analysis of oocyte size/frequency data, and comparison of different types of data. Journal of Invertebrates Reprodroduction. 6: 271-283.

Holme, N.A. and McIntyre, A.D. 1971. Methods for the study of marine benthos. Blackwell Scientific Publications. Oxford and Edinburgh.

Lamprell, K. and Healy, J. 1998. Bivalves of Australia. Backhuys Publishers. Leiden.

Myrand, B., Guderley, H. and Himelman, J.H. 2000. Reproductive and summer mortality of blue mussels Mytilus edulis in the Magdalen Island, Southern Gulf of St. Lawrence. Marine Ecological Progress Series 197: 193207.

Morton, B. 1988. The population dynamics and reproductive cycles of Brachidontes variabilis (Bivalvia: Mytilidae) in Hong Kong mangrove. Malacology Review 21: 109-117.

Pouvreau, S., Gangnery, A., Tiapari, J., Lagarde, F., Garnier, M. and Bodoy, A. 2000. Gametogenic cycle and reproductive of the tropical blacklip pearl oyster, Pinctada margaritifera (Bivalve: Pteriidae), cultivated in Takapoto atoll (French Polynesia). Aquatic Living Resouces 13 (1): 37 - 48.

Rodhouse, P.G., Roden, C.M., Burnel, G.M., Hensey, M.P., McMahon, T., Ottaway, B. and Ryan. 1984. Food resources, gametogenesis, and growth of Mytilus edulis on the shore and in suspended culture: Killary Harbour, Ireland. Journal of Marine Biology Assosiation of United Kingdom. 64: 513-529. 
Shepherd, S.A. and Thomas, I.M. 1989. Marine invertebrates of southern Australia. Part II. South Australian government Printing Division. Adelaide.

Svane, I. and Ompi, M. 1993. Patch dynamics in beds of the bule mussel Mytilus edulis L.: effects of site, patch size, and position within a patch. Ophelia. 37: 187-202.

Sweeney, M.L. and Walker, R.L. 1989. The gametogenic cycle of Brachidontes exustus (Linne, 1758) (Bivalvia: Mytilidae): at Wassaw Island, Georgia. American Malacological Bulletin. 14 (2): $149-156$

Toro, J.E., Thompson, R.J. and Innes, D.J. 2002. Reproductive isolation and reproductive output in two sympatric mussel species (Mytilus edulis, M. trossulus) and their hybrids from Newfoundland. Marine Biology 141: 897-909.

Thorarinsd'ottir, G.G. 1996. Gonad development, larval settlement and growth of Mytilus edulis L. in a suspended population of Mytilus edulis L. in a suspended population in Hvalfj'ordur, South-West Iceland. Aquactic Research 27: 57-65.

Wisely, B. 1964. Aspects of reproduction, settling and growth in the mussel Mytilus edulis planulatus Lamarck. Journal Malacological Society of Australia 8: 25-30.

Wilson, B.R. and Hodgkin, E.P. 1967. A comparative account of the reproductive cycles of five species of marine mussels (Bivalvia: Mytilidae) in the vicinity of Fremantle, Western Australia. Australian Journal of Marine Freshwater Research 18: 175-203.

Zardus, J.D. and Martel, A.L. 2002. Phylum Mollusca: Bivalvia. In: Young, C.M., Sewell, M. A., and Rice, M.E. (Editors). Atlas of marine invertebrate larvae. Academic Press, San Diego, USA. Pp. 289-301. 